\title{
Ocular Injuries Resulting from the Rotary Power Mower
}

\author{
Shinji Kurimoto, Yuichiro Ino, Yayoi Nomura, Tsunetami Nomura, \\ Kyoichi OKUBO and Tsuneto IWASAKI \\ Department of Ophthalmology, University of Occupational and Environmental Health, \\ Japan. Kitakyushu 807, Japan
}

\begin{abstract}
The development and popularity of the rotary power mower has created ocular injuries among both farmers and urban dwellers. Five cases of ocular injuries over the past year resulting from a new type of rotary power mower are reported by the authors. Two of them became blind. We believe it is necessary to improve the machine and strongly advocate the use of safety goggles.
\end{abstract}

Key words: rotary power mower, ocular injuries, traumatic cataract, blindness.

(Received 16 February 1982)

\section{Introduction}

Ocular injuries due to rotary power mowers have already been reported (White, 1957; Barsky, 1960; Fenton, 1965; Kenny \& Everding, 1966). The blades of the machine attain speeds of 2,000 to 4,000 rpm. Small objects, such as pieces of glass, stones, or metallic fragments, when they come into contact with the blade, may be converted into missiles with a velocity of approximately 300 feet per second, which approaches the speed of a bullet. Not only ocular injuries but also an accidental death from such missiles have been reported (White, 1957).

In Japan, a new type of rotary power mower (Fig. 1) has become tremendously popular during the past few years, because of the ease in handling and efficiency of performance. However, a startling increase in number and seriousness of injuries inflicted by the mowers has been noticed.

Five cases of ocular injuries due to the rotary power mowers were examined in our clinic from May, 1980 to May, 1981.

\section{Report of Cases}

Case 1.

A 51-year-old teacher of an agriculture high school, male.

On May 3, 1981, a piece of a soft drink bottle broken by a rotary power mower struck his left eye.

His prolapsed iris was excised on the day of injury. 


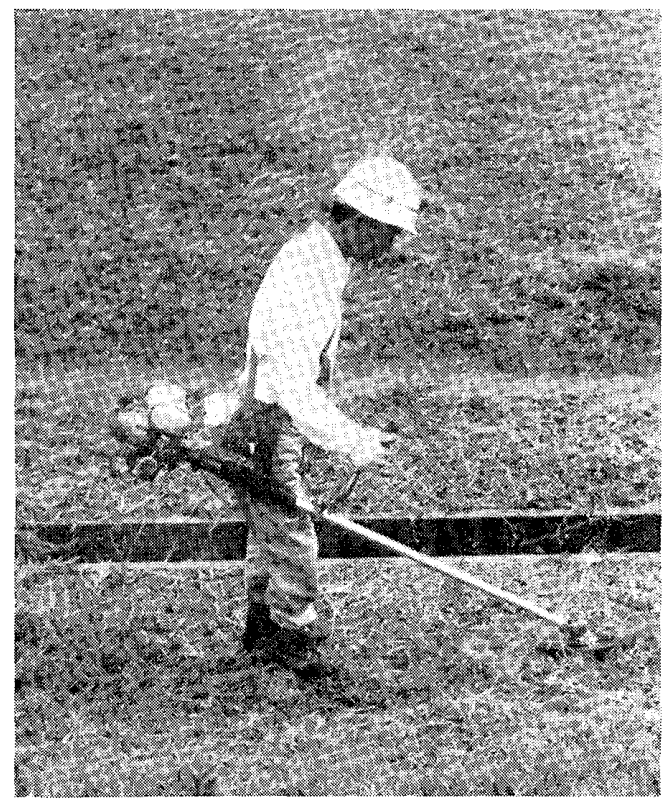

Fig. 1. A new type of rotary power mower.

On May 26, the patient was introduced to our clinic and visual acuity in the left eye was 0.1 (n. c.).

$\mathrm{X}$-ray examination revealed no radiopaque foreign body in the eye.

Cystoid macular edema with poolings of fluorescein was discovered.

\section{Case 2.}

A 72-year-old male farmer.

On May 6, 1980, pieces of broken blade of a rotary power mower hit the left eye.

Although one of the two intraocular foreign bodies was removed with a magnet by an ophthalmologist, the other foreign body remained in the iris.

Visual acuity of the left eye was 0.02 (n. c.).

On May 8, the patient was introduced to our clinic.

Corneal laceration, anterior synechias, a foreign body in the iris, and a traumatic cataract were discovered.

On May 9, the corneal wound was repaired by sutures of nylon, and the foreign body was removed with a magnet.

Phacoemulsification for the traumatic cataract was performed and a Binkhorst type iridocapsular two-loop lens has been implanted.

On November 18th, 1980, visual acuity of the eye was $0.3(0.9 \times-2.5 \mathrm{D})$.

\section{Case 3.}

A 27-year-old office man.

On August 7, 1980, a stone thrown by a rotary power mower struck his left eye. 
On August 30, 1980, he was examined in our clinic because the visual acuity remained at 0.3 (n.c.).

Choroidal bemorrhage and commotio retinae were found.

Case 4.

A 47-year-old male farmer.

On May 23, 1980, a stone thrown by a rotary power mower struck his left eye. The following day, on examination, it was found that the visual acuity was h. $\mathrm{m} . / 30 \mathrm{~cm}$ (n. c.) and there were laceration of the upper lid and vitreous hemorrhage.

$\mathrm{X}$-ray examination of the eye revealed a radiopaque intraocular foreign body.

Vitreous surgery was performed unsuccessfully in another hospital.

At present there is no light perception in the eye.

\section{Case 5 .}

A 32-year-old male farmer.

On May 25, 1980, a stone thrown by a rotary power mower hit his right eye.

The visual acuity was f. n. $/ 30 \mathrm{~cm}$ (n. c.).

Laceration of the sclera and vitreous hemorrhage were seen.

The eye was enucleated in another hospital.

\section{Discussion}

Five cases of ocular injuries resulting from the new type of rotary power mower were examined for the first time in our clinic from May, 1980 to May, 1981. Two of them became blind.

In a study of 15 cases of ocular injuries due to the new type of rotary power mower, Asayama et al. (1980) reported an increase in number ( 1 case in 1974, 2 cases in 1975, 1 case in 1976, 1 case in 1977, 3 cases in 1978 and 7 cases in 1979) and the seriousness of cases (visual acuity of 8 out of 15 cases remained below 0.04 (n. c.). In their prefecture, Yamaguchi Prefecture, 33, 258 of the new type of the rotary power mower in 1973, 41, 462 mowers in 1974, 46, 683 mowers in 1975, 47, 635 mowers in 1976, 54, 361 mowers in 1977 and 57,763 mowers in 1978, were used in agriculture alone. The mower is used not only by farmers but urban dwellers as well. Because of the ease in handling this power mower, it has become popular among both young and old resulting in higher yearly sales than those noted here.

Although no investigation for the whole country regarding the popularity of the mower and frequency of injuries has been done and only one article, as noted here, by Asayama et al. (1980) has been written, it can be presumed that a sizable number of cases of rotary power mower related injuries have occurred in Japan.

One of our five cases was due to a piece of a soft drink bottle broken by the mower, 
three of the cases were due to stones thrown by the mower. In using the mower special attention should be paid to avoid bringing the blades into contact with glass, stones or metallic objects.

One of our cases was due to pieces of a broken blade. The quality of blades should be improved and old blades should not be used.

To prevent injuries by the above mentioned missiles, the safety cover should not be removed from the mower. Because those missiles may also injure persons standing nearby, people should always be kept at a safe distance. Safety goggles should be used by the operator. Although the use of a whole face protector is desirable, such a protector is not practical because the mower is used mainly in summer.

Eight of Asayama's cases with traumatic cataract and one of our cases were observed. Phacoemulsification is indicated for cases of traumatic cataract with soft nucleus of the lens. The operation should be done early, before any occurrence of fibrous change such as posterior synechia.

The traumatic cataract of the one eye in our case also indicated intraocular lens implant surgery and following surgery, the patient obtained useful binocular and steroscopic vision.

\section{References}

Asayama, T., Kometani, J., Saito, K. et al. (1980): Eye injuries due to motor-mowers. J. Japan Acci. Med. Assoc., 28: 584-587. (in Japanese)

Barsky, D. (1960): Eye injuries due to power lawn mowers. Arch. Ophthalmol., 64: 385-387.

Fenton, R. H. (1965): Power lawn mowers as a source of ocular injuries. Amer. J. Ophthal., 59: 312-314.

Kenny, N. J. \& Everding, K. P. (1966): Motor-mower injuries. Med. J. Aust., 2: 547. White, W.L. (1957): The menace of the rotary lawn mower. Amer. J. Surg., 93: 674-675.

動力草杊り機による眼外傷

栗本 晋二・猪野 雄一郎・野村 弥生・野村 恒民・大久保 袁一・岩崎 常人 産業医科大学眼科学教室

要 旨：我が国における新型動力草刚り機の著しい普及に伴い，その草刈り機による眼外傷の増加 が注目されている。過去 1 年間に経験した，新型幕刈り機による眼外傷の 5 例について報 告した。うち 2 例は失明した。事故防止のため機器の改良，防護眼鏡の装用が必要である。

J. UOEH（癄業医大誌），4 (2)：165-168（1982） 